\title{
In vitro Study of Topical Antiseptics Used to Treat Mycological Gill Rot Disease in Cyprinus carpio
}

\author{
Abbas Razzaq Abed*, Aleem Mardas Khudhair and Ibtisam Mohammed Hussein \\ Al-Furat Al-Awsat Technical University, Technical Institute of Babylon, Iraq.
}

\begin{abstract}
Antiseptics are widely used in fish diseases to control the growth of fungal on living tissues (External body surface and Gills). The current study included the antifungal effects of antiseptics (Malachite green $5 \mathrm{mg} / \mathrm{l}$, Methylene blue $10 \mathrm{mg} / \mathrm{I}$, Potassium permanganate $20 \mathrm{ppm}, \mathrm{NaCl} 5 \%$, Quaternary ammonium 0.5 $\mathrm{ml} / \mathrm{l}$, Copper sulfate $0.5 \mathrm{mg} / \mathrm{l}$, Formalin $250 \mathrm{ppm}$ and Povidone iodine $100 \mathrm{mg} / \mathrm{l}$ ) against Branchiomyces sanguinis, where several laboratory tests were used to evaluated the antifungal activity of antiseptics that used in the this study include Minimum inhibitory concentration, Spore growth test, Radial growth assay, Agar-well diffusion method of sensitive test. The results showed that Malachite green, Copper sulfate, Quaternary ammonium and Formalin were highly effectiveness against Branchiomyces sanguinis, while the Methylene blue, Potassium permanganate, $\mathrm{NaCl}$ and Povidone iodine were least effective in comparison with other antiseptics used in this study.
\end{abstract}

Keywords: In vitro, topical antiseptics, mycological Gill rot, Cyprinus carpio.

*Correspondence: dr_abas2008@yahoo.com, Alim.mrdas31071978@gmail.com, Ibtisam2017muh@gmail.com

(Received: 02 February 2019; accepted: 04 March 2019)

Citation: Abbas Razzaq Abed, Aleem Mardas Khudhair and Ibtisam Mohammed Hussein, In vitro Study of Topical Antiseptics Used to Treat Mycological Gill Rot Disease in Cyprinus carpio, J Pure Appl Microbiol., 2019; 13(1):537-544 doi: 10.22207/JPAM.13.1.60

(C) The Author(s) 2019. Open Access. This article is distributed under the terms of the Creative Commons Attribution 4.0 International License which permits unrestricted use, sharing, distribution, and reproduction in any medium, provided you give appropriate credit to the original author(s) and the source, provide a link to the Creative Commons license, and indicate if changes were made. 


\section{INTRODUCTION}

The common carp is one of type of fish also called European carp and it is scientific name (Cyprinus carpio) is a live in the freshwater lakes and large rivers in Asia, Europe, Africa, America and Oceania. Carp are considering invasive Organism because early maturity, generalized diet, tolerance to ecosystem, rapid growth, highly dispersive in the environment and high reproductive capacity (Koehn et al., 2016). Fish diseases affect the survival and growth rates resulting to poor yield (both in quantity and quality). Because of the high cost of medicines used for fish, so fish diseases lead to a decline in production and cause significant economic losses (Idowu et al., 2017). Gill- rot disease is a mycological fish disease involving Gill tissues, affecting of fish live in the freshwater. The disease is caused by Branchiomyces demigrans and Branchiomyces sanguinis. Gills infected are characterized by necrosis and congestion (Sen and Mandal, 2018). Antiseptics are biocides that inhibit or destroy of microorganisms growth in or on living cells of tissues (Block, 1991), Antiseptics are currently used to treat fungal fish diseases that affect the outer surface of the fish or their Gills, and as a result of different infections fungi have emerged several types of antiseptics. For the first time in history, Iraq witnessed a major environmental disaster and economic loss resulting from the loss of millions of fish in the Tigris and Euphrates rivers as a result of the Gills rot fungal disease that occurred in October of 2018. The most important characteristic of this disaster is the floating of fish on the surface of the water and its transfer to various areas of southern Iraq, for that the current study aimed to evaluate the most important local antiseptics used to treat Branchiomyces sanguinis in common carp fish.

\section{MATERIALS AND METHODS \\ Branchiomyces sanguinis isolates}

B. sanguinis isolates were taken from microbial banking which follow to Microbiology lab. /Community health Dept. /Babil institute technique.

Topical antiseptics

In this study used eight agents of most common antiseptics agents were used in fungal fish diseases include Malachite green
$5 \mathrm{mg} / \mathrm{l}$, Methylene blue $10 \mathrm{mg} / \mathrm{l}$, Potassium permanganate $20 \mathrm{ppm}, \mathrm{NaCl} 5 \%$, Ammonium 0.5 $\mathrm{ml} / \mathrm{l}$, Copper sulfate $0.5 \mathrm{mg} / \mathrm{l}$, Formalin $250 \mathrm{ppm}$ and Povidone iodine $100 \mathrm{mg} / \mathrm{l}$.

All of above agents were used to evaluate the best activity as antifungal when used in the treatment fungal Gills rot disease (Branchiomyces sanguinis).

\section{Spore count of Branchiomyces sanguinis Spore counts}

B. sanguinis spores count were calculated according to (By a method prepared by researchers). After $B$. sanguinis was cultured on the PDA medium at $28 \div C$ for 10 days. Two pieces of the PDA medium, which contains fungal growth, were taken by a cork borer (Number 2: diameter $5 \mathrm{~mm}$ ) then put in a glass test tube containing $5 \mathrm{ml}$ of sterile saline water. The glass tube is then shaken by the vortex apparatus so that the spores can be spread in the saline solution. By using a haemocytometer method the spores concentration in glass test tube was determined . One drop of the spores suspension was added into hemocytometer chamber, spores were calculated under high power 40X of light microscope using the following equation (Nasiru et al., 2015).

Spores $/ \mathrm{ml}=\mathrm{N} \times 10^{\wedge} 4$,

Where: where $n=$ the average cell count per square of the four corner squares counted.

Finally, total number of spore suspension in the one $\mathrm{ml}$ of saline water should be equal to $10^{\wedge} 7$ spore $/ \mathrm{ml}$.

\section{Spores growth test}

According to Hussein et al. (2018) method With simple modulation. This test aimed to detect the viability spores growth after treated with antiseptics (Malachite green $5 \mathrm{mg} / \mathrm{l}$, Methylene blue $10 \mathrm{mg} / \mathrm{I}$, Potassium per-manganate $20 \mathrm{ppm}$, $\mathrm{NaCl} 5 \%$, Ammonium $0.5 \mathrm{ml} / \mathrm{l}$, Copper sulfate 0 . $5 \mathrm{mg} / \mathrm{l}$, Formalin $250 \mathrm{ppm}$ and Povidone iodine $100 \mathrm{mg} / \mathrm{l}$ ). Eight containers (Capacity $50 \mathrm{ml}$ ) were used, each container for each concentration and it filled with $50 \mathrm{ml}$ of final concentration were used as antiseptics to treat $B$. sanguinis, then $300 \mu$ l of $B$. sanguinis spores $\left(1 \times 10^{\wedge} 7 \mathrm{spore} / \mathrm{ml}\right)$ were added in each container and mixed well. The containers were incubated for 24 hours at $28^{\circ} \mathrm{C}$. After end time of incubation period, two hundred microliter were taken from each container by micropipette (Volume 100-1000 $\mathrm{\mu l}$ ) then put on the surface 
of PDA agar and diffused on the surface media by using glass spreader and cultured on the PDA agar and were incubated again for 5 days at $28^{\circ} \mathrm{C}$. Note:- Sterilization of PDA gar by autoclave at temperature $121^{\circ} \mathrm{C}$, For 15 mints at $15 \mathrm{lbs}$.

Minimum-inhibitory concentration (MIC)

MIC procedure was occurred by tube dilution Method (Cruickshank et al., 1975) was used to determine the MIC values for antiseptics agents that used in this study.

According to this method 10 test tubes with $8 \mathrm{ml}$ of Potatoes Dextrose Broth (PDB) were used for each antiseptic. To each first tube was added $2 \mathrm{ml}$ of the each concentration (Malachite green $10 \% \mathrm{w} / \mathrm{v}$, Methylene blue $25 \% \mathrm{w} / \mathrm{v}$, Potassium permanganate $25 \% \mathrm{w} / \mathrm{v}, \mathrm{NaCl} 50 \%$ $\mathrm{w} / \mathrm{v}$, quaternary Ammonium 50\% v/v, Copper sulfate $50 \% \mathrm{w} / \mathrm{v}$, Formalin $37 \% \mathrm{w} / \mathrm{v}$ and Povidone iodine $10 \% \mathrm{w} / \mathrm{v})$. and serial two fold dilution was done from $1^{\text {st }}$ tube to the $10^{\text {th }}$ tube and two $\mathrm{ml}$ of solution (media + antiseptic) were discarded from the 10th tube. one hundred $ל / 1$ of inoculums (B. sanguinis spores [ $1 \times 0^{\wedge} 7$ spore $\left./ \mathrm{ml}\right]$ ) was added for each tube. All test tubes were incubated for 5 days at $28^{\circ} \mathrm{C}$. The MIC value was regarded as the lowest concentration that did not yield any fungal growth on the broth medium used.

\section{Radial growth assay}

According to equation $\mathrm{V}_{1} \mathrm{C}_{1}=\mathrm{V}_{2} \mathrm{C}_{2}$, Original stock antiseptics agents (Malachite green $10 \% \mathrm{w} / \mathrm{v}$, Methylene blue $10 \% \mathrm{w} / \mathrm{v}$, Potassium permanganate $10 \% \mathrm{w} / \mathrm{v}, \mathrm{NaCl} 20 \% \mathrm{w} / \mathrm{v}$, Quaternary Ammonium $50 \% \mathrm{v} / \mathrm{v}$, Copper sulfate $20 \% \mathrm{w} / \mathrm{v}$, Formalin $37 \%$ $\mathrm{w} / \mathrm{v}$ and Povidone iodine $10 \% \mathrm{w} / \mathrm{v}$ ) were mixed with PDA media (200ml PDA media were used for each antiseptics conce-ntration) after sterilization by Autoclave apparatus (At temperature $121^{\circ} \mathrm{C}$, for 15 mints, $15 \mathrm{lbs}$ ) to obtain on Malachite green $5 \mathrm{mg} / \mathrm{l}$, Methylene blue $10 \mathrm{mg} / \mathrm{l}$, Potassium per-manganate $20 \mathrm{ppm}, \mathrm{NaCl} 5 \%$, Quaternary Ammonium $0.5 \mathrm{ml} / \mathrm{l}$, Copper sulfate $0.5 \mathrm{mg} / \mathrm{l}$, Formalin $250 \mathrm{ppm}$ and Povidone iodine $100 \mathrm{mg} / \mathrm{l}$. By using sterilized cork borer, $5 \mathrm{~mm}$ diameter discs of PDA media contain B. sanguinis mycelia were cut from petri dish was contain colony aged about 10 days, then transferred in the center of PDA media which contains on the different antiseptics agents according to previous prepared concentrations. All previous petri dishes as well as control positive petri dishes (PDA medial cultured by $B$. sanguinis only) and control negative petri dishes (PDA medial without cultured by $B$. sanguinis) were incubated for 10 days at $28^{\circ} \mathrm{C}$. After end of incubation period, radial growth diameter of $B$. sanguinis were measured in each petri dish (Mohit et al., 2013). Note:-Petri dishes of control positive and negative were used as a groups compare with other antiseptics groups. Number of petri-dish for each group repeated ten times.

\section{Agar-well diffusion method of sensitive test}

Agar - well diffusion method is one of famous method used to evaluate the antimicrobial substances activity. (Magaldi et al., 2004). One hundred microliter were taken from spore suspension $\left(1 \times 10^{\wedge} 7 \mathrm{spore} / \mathrm{ml}\right)$ by micro-

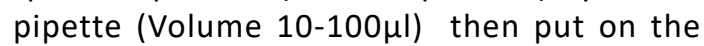
surface of PDA agar and diffused on the surface media by using glass spreader. All petri dishes which contain PDA ager left for one hour to dry of spores of $B$. sanguinis on the media surface. Then, by using a sterile cork borer, a hole with a diameter of eight $\mathrm{mm}$ is punched aseptically in the center of PDA agar, these holes later fill with 100 $\mathrm{ml}$ for each antiseptics concentration were used in this study. Then, agar plates are incubated for 5 days at $28^{\circ} \mathrm{C}$. Control positive PDA agar (Surface of PDA ager media contain spores but holes contain distilled water only) and negative group (PDA ager media only). After end of incubation period, Zone of inhibition around the well for each antiseptics agents and positive control group were determined by measuring by Vernier caliper. Number of petri-dish for each antiseptic and control group (positive and negative) repeated ten times.

\section{Statistical data analysis}

Statistical differences between groups (Antiseptics group and control group) was determined by using Statistical Package for the Social Sciences (SPSS, Version 20) and compared between them by one way analysis of variance (ANOVA) followed by least-significant-difference (LSD) and the minimum level of significance was $p<0.05$.

\section{RESULTS AND DISCUSSION}

The current study shows that there are differences in the response to antiseptics used against $B$. sanguinis. Malachite green, Quaternary 
ammonium, Copper Sulfate and Formalin were showed highly effective against $B$. sanguinis in comparison with other antiseptics used. While Methylene blue, Potassium permanganate, $\mathrm{NaCl}$, and Povidone iodine showed least effective against same fungal according to the tests conducted in this study which include (Minimum inhibitory concentration, table 1, Spores growth test, fig. 1, Inhibition zone diameter, table 2, fig. 2 and Radial growth diameter, table 3, fig. 3.

Microscopic appearance of $B$. sanguinis mycelium were noticed different deformity depend on the type of antiseptic used

Mycelium of $B$. sanguinis cultivated
Table1. Minimum inhibitory concentration value for different antiseptics used.

\begin{tabular}{|c|c|}
\hline Antiseptics & MIC value \\
\hline Malachite green & $0.8 \mathrm{mg} / \mathrm{ml}$ \\
\hline $\begin{array}{l}\text { Methylene blue } \\
\text { Potassium }\end{array}$ & $0.8 \mathrm{mg} / \mathrm{ml}$ \\
\hline permanganate & $20 \mathrm{mg} / \mathrm{ml}$ \\
\hline $\mathrm{NaCl}$ & $40 \mathrm{mg} / \mathrm{ml}$ \\
\hline $\begin{array}{l}\text { Quaternary } \\
\text { ammonium }\end{array}$ & $800 \mu \mathrm{l} / \mathrm{ml}$ \\
\hline Copper sulfate & $1.6 \mathrm{mg} / \mathrm{ml}$ \\
\hline Formalin & $0.592 \mathrm{mg} / \mathrm{ml}$ \\
\hline lodine & $20 \mathrm{mg} / \mathrm{ml}$ \\
\hline
\end{tabular}

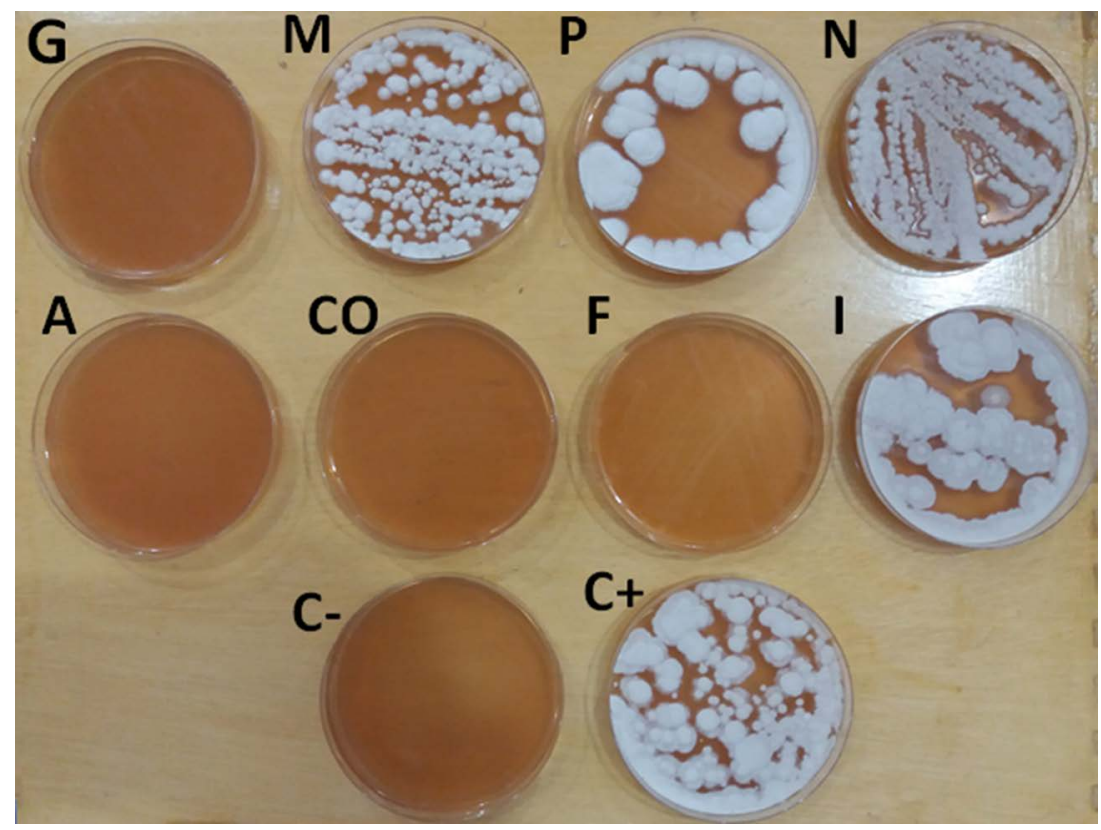

Fig. 1. Spore growth test, $G=$ Malachite green $5 \mathrm{mg} / \mathrm{l}, \mathrm{M}=$ Methylene blue $10 \mathrm{mg} / \mathrm{l}, \mathrm{P}=$ Potassium permanganate 20 ppm , $\mathrm{N}=\mathrm{NaCl} 5 \%, \mathrm{~A}=$ Quaternary ammonium $0.5 \mathrm{ml} / \mathrm{I}, \mathrm{CO}=$ Copper sulfate $0.5 \mathrm{mg} / \mathrm{l}, \mathrm{F}=$ Formalin $250 \mathrm{ppm}$ and $\mathrm{I}=$ Povidone iodine $100 \mathrm{mg} / \mathrm{l}, \mathrm{C}+=$ Control positive, $\mathrm{C}-=$ Control negative.

on the PDA media which containing Malachite green $5 \mathrm{mg} / \mathrm{l}$, Quaternary ammonium 10mg/0.5 $\mathrm{ml} / \mathrm{l}$, copper sulfate $0.5 \mathrm{mg} / \mathrm{l}$ and Formalin 250 ppm were characterized by narrowing the fungal filaments and not coloring it with the lactophenol cotton blue dye while, mycelium of $B$. sanguinis cultivated on the PDA media which containing Methylene blue $10 \mathrm{mg} / \mathrm{I}, \mathrm{NaCl} 5 \%$, Povidone iodine $100 \mathrm{mg} / \mathrm{l}$, Potassium permanganate 20 ppm were characterized by similar in structure to the fungus mycelium in the control group, fig. 4.
Fungicidal effects of Copper sulfate, Quaternary ammonium, Malachite green and Formalin on the $B$. sanguinis led to prevent it grow in the PDA media, this result may be come from the variety of mechanism of action for these agents on the cell structures of $B$. sanguinis. Copper sulfate have fungicidal effect on the fungal mycelium growth and conidia by Copper ions could be attributed to which can catalyze the production of highly hydroxyl radicals $(\bullet \mathrm{OH})$, with subsequent defect to DNA, proteins, lipids, and Biomolecules, 
Table 2. Inhibition zone diameter of $B$. sanguinis in the PDA media, by Agar-well diffusion method, for different antiseptics used and in comparison with control positive and negative.

\begin{tabular}{lll}
\hline Antiseptic & $\begin{array}{c}\text { Inhibition zone } \\
(\mathrm{mm}) \mathrm{M} \pm \mathrm{SE}\end{array}$ \\
\hline Malachite green $5 \mathrm{mg} / \mathrm{l}$ & $23.20 \pm 0.58$ & $\mathrm{~A}$ \\
Methylene blue $10 \mathrm{mg} / \mathrm{l}$ & $00.00 \pm 00.00$ & $\mathrm{~B}$ \\
Potassium permanganate & $00.00 \pm 00.00$ & $\mathrm{~B}$ \\
$20 \mathrm{ppm}$ & & \\
NaCl 5\% & $00.00 \pm 00.00$ & $\mathrm{~B}$ \\
Quaternary ammonium & $28.40 \pm 0.37$ & $\mathrm{CD} \mathrm{E}$ \\
0.5ml/l & & \\
Copper sulfate 0.5mg/l & $28.20 \pm 0.37$ & $\mathrm{D}$ \\
Formalin 250 ppm & $29.20 \pm 0.58$ & $\mathrm{E}$ \\
Povidone iodine $100 \mathrm{mg} / \mathrm{l}$ & $00.00 \pm 00.00$ & $\mathrm{~B}$ \\
C+ & $00.00 \pm 00.00$ & $\mathrm{~B}$ \\
C- & $00.00 \pm 00.00$ & $\mathrm{~B}$ \\
\hline
\end{tabular}

$\mathrm{LSD}=0.74$

Different capital letters denote significant results ( $p$-value $<0.05$ ) between differentgroups.

also extensive copper ions induced membrane integrity disruption which leads to loss of cell permeability (Kumbhar et al.,1991). Quaternary ammonium are considered to be membrane active substances (McDonnell and Russell, 1999). In microorganism cells exposed to Quaternary ammonium, have ability of adsorption and
Table 3. Radial growth diameter of $B$. sanguinis in the PDA media, for different antiseptics used and in comparison with control positive and negative group.

\begin{tabular}{lll}
\hline Antiseptic & $\begin{array}{l}\text { Radial growth } \\
\text { diameter }(\mathrm{mm})\end{array}$ \\
\hline Malachite green $5 \mathrm{mg} / \mathrm{l}$ & $13.20 \pm 0.37$ & $\mathrm{~A}$ \\
Methylene blue $10 \mathrm{mg} / \mathrm{l}$ & $63.00 \pm 1.00$ & $\mathrm{~B}$ \\
Potassium permanganate & $62.40 \pm 1.02$ & $\mathrm{~B}$ \\
20 ppm & & \\
NaCl 5\% & $22.40 \pm 092$ & $\mathrm{C}$ \\
Quaternary ammonium & $7.80 \pm 1.49$ & $\mathrm{D}$ \\
0.5ml/I & & \\
Copper sulfate 0.5mg/l & $6.60 \pm 0.50$ & $\mathrm{D}$ \\
Formalin 250 ppm & $6.40 \pm 0.40$ & $\mathrm{D}$ \\
Povidone iodine 100mg/l & $72.60 \pm 0.87$ & $\mathrm{E}$ \\
C+ & $72.60 \pm 0.67$ & $\mathrm{~F}$ \\
C- & $00.00 \pm 00.00$ & $\mathrm{G}$ \\
\hline
\end{tabular}

\section{LSD $=1.98$}

Different capital letters denote significant results ( $p$-value $<0.05$ ) between different groups.

penetration of cell wall and reaction with the cell cytoplasmic membrane followed by membrane disorganization, degradation of nucleic acids and proteins, leakage into intracellular structures (low molecular weight material) and finally lead to cell wall lysis caused by the autolytic enzymes (Tischer et al., 2012). Formaldehyde (FD) act by induced

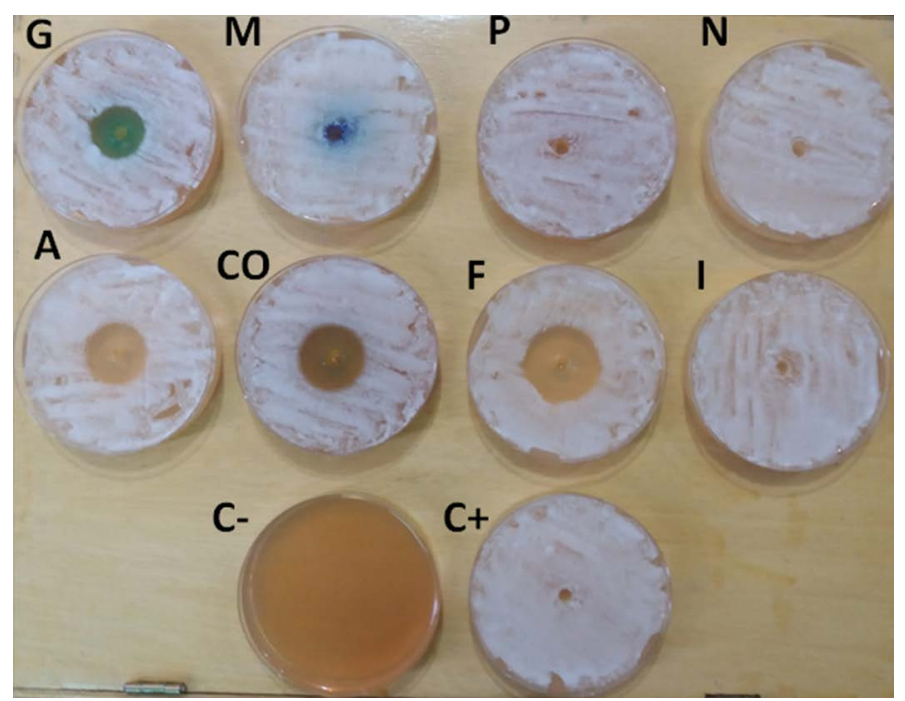

Fig. 2. Inhibition zone diameter, $G=$ Malachite green $5 \mathrm{mg} / \mathrm{l}, \mathrm{M}=$ Methylene blue $10 \mathrm{mg} / \mathrm{I}, \mathrm{P}=$ Potassium permanganate $20 \mathrm{ppm}, \mathrm{N}=\mathrm{NaCl} 5 \%, A=$ Quaternary ammonium $0.5 \mathrm{ml} / \mathrm{l}, \mathrm{CO}=$ Copper sulfate $0.5 \mathrm{mg} / \mathrm{l}, \mathrm{F}=$ Formalin $250 \mathrm{ppm}$ and $\mathrm{I}=$ Povidone iodine $100 \mathrm{mg} / \mathrm{l}, \mathrm{C}+=$ Control positive, $\mathrm{C}-=$ Control negative. 


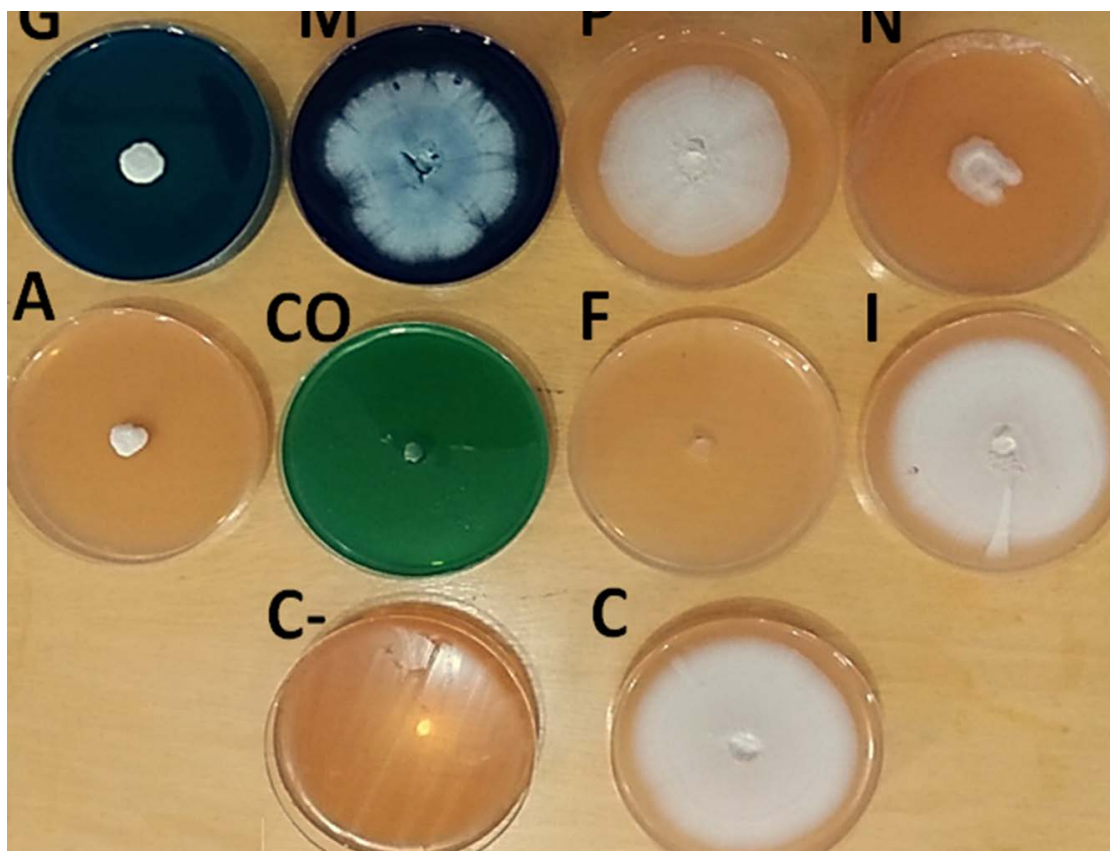

Fig. 3. Radial growth diameter test, $G=$ Malachite green $5 \mathrm{mg} / \mathrm{I}, \mathrm{M}=$ Methylene blue $10 \mathrm{mg} / \mathrm{I}, \mathrm{P}=$ Potassium permanganate $20 \mathrm{ppm}, \mathrm{N}=\mathrm{NaCl} 5 \%, \mathrm{~A}=$ Quaternary ammonium $0.5 \mathrm{ml} / \mathrm{I}, \mathrm{CO}=$ Copper sulfate $0.5 \mathrm{mg} / \mathrm{l}, \mathrm{F}=$ Formalin $250 \mathrm{ppm}$ and $\mathrm{I}=$ Povidone iodine $100 \mathrm{mg} / \mathrm{I}, \mathrm{C}+=$ Control positive, $\mathrm{C}-=$ Control negative.
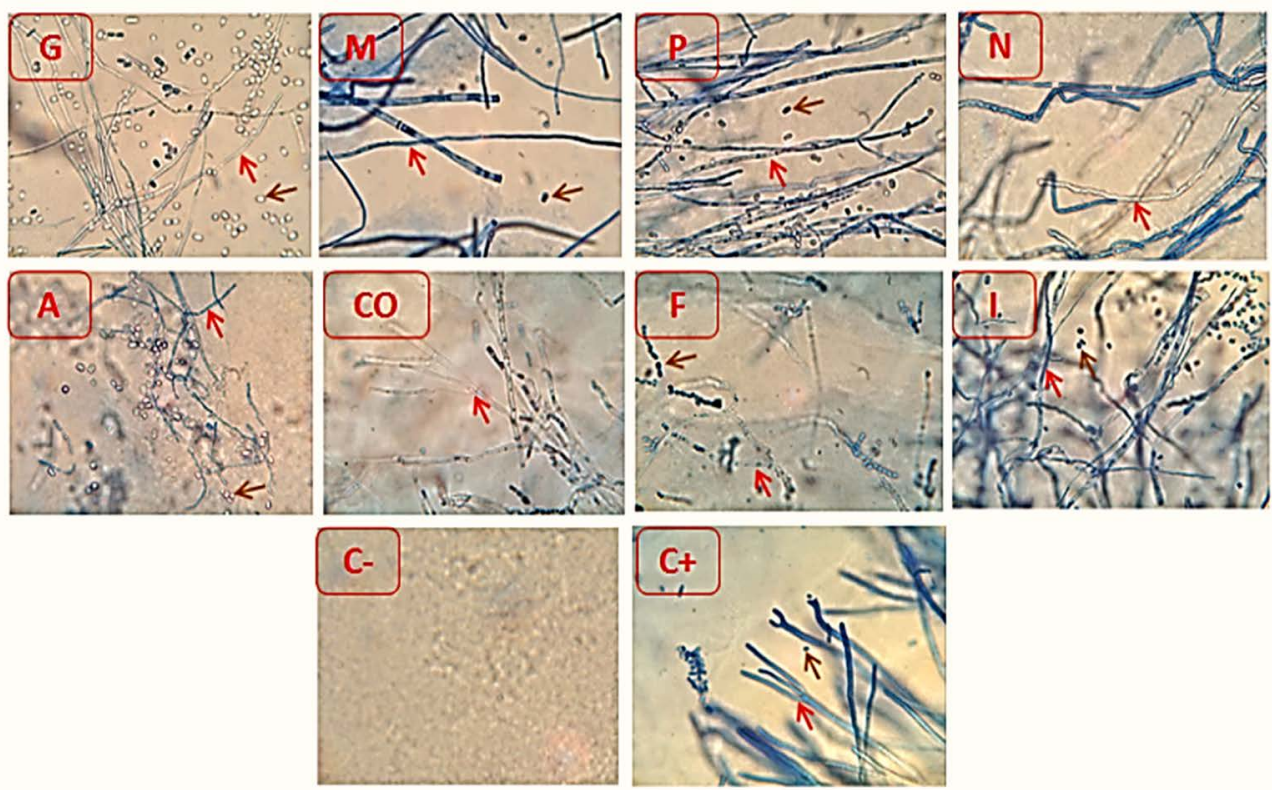

Fig. 4. Microscopic appearance of $B$. sanguinis growing tops on PDA media after mixed with different antiseptics, $\mathrm{G}=\mathrm{PDA}$ media mixed with Malachite green at concentration $5 \mathrm{mg} / \mathrm{l}, \mathrm{M}=\mathrm{PDA}$ media mixed Methylene blue at concentration $10 \mathrm{mg} / \mathrm{l}, \mathrm{P}=\mathrm{PDA}$ media mixed Potassium permanganate at concentration $20 \mathrm{ppm}, \mathrm{A}=\mathrm{PDA}$ media mixedwith Quaternary ammonium, N= PDA media mixed with $\mathrm{NaCl}$ at concentration $5 \%, \mathrm{CO}=\mathrm{PDA}$ media mixed Copper sulfate at concentration $0.5 \mathrm{mg} / \mathrm{I}, \mathrm{F}=\mathrm{PDA}$ media mixed Formalin at concentration $250 \mathrm{ppm}$ and I= PDA media mixed Povidone iodine at concentration $100 \mathrm{mg} / \mathrm{ml}$. C+=control positive, $\mathrm{C}-=$ Control negative. 
cross - links as biomarkers, and the ability of FD to cause Genetic material defect ,Also FD is highly reactive with DNA to form DNA-DNA and (DDX) DNA-protein (DPX) cross - links. (Bogdanffy et al., 1987). Mitochondria as the major cellular targets of Malachite green in both fish and mammals (Zahn and Braunbeck, 1995), Malachite green (MG) have a toxic effects on the mitochondria activates (Srivastava et al., 2004)., by promoting a dissipation of mitochondrial membrane potential followed swelling of mitochondrial. This mitochondrial permea-bilization transition was followed by respiratory inhibition attributable to cytochrome c release and was caused by the oxidation of $\mathrm{NAD}(\mathrm{P}) \mathrm{H}$ (Kowaltowski et al., 1999), in same time the carbinol base form of MG is more lipophilic and can directly effects on the lipid bilayer of cell membranes by disrupt it and resulting in an increase in membrane permeability (Srivastava et al., 2004) . When the potential of mitochondrial membrane is lost, cells will damage by the programmed cell death eight protein (apoptosis inducing factor) is released from the mitochondria structure and enters into cytosol and finally ends up in the nucleus of cell where it binds to genetic matter (DNA) in a sequenceindependent manner. This normally starts a signal transduction resulting in the induction of a caspase enzyme-independent pathway of apoptosis by causing Deoxyribonucleic acid fragmentation and condensation of chromosome (Bras et al., 2005) in addtion, the concentration of antiseptics (Copper sulfate, Quaternary ammonium, Malachite green and Formalin) used in current study were very appropriated to kill or inhibit of $B$. sanguinis.

\section{Other antiseptics used}

Methylene blue (Affecting by produces high energy species that have the potential to damage proteins, lipids and genetic material (DNA), Also have a potential mechanism is the inhibition of NO synthase, with possible generation of superoxide anions) (Epe and Wild., 1989), Potassium permanganate (Affecting by damaging the cell membrane by oxidation of cell membrane associated molecules, leading to increased cell permeability), $\mathrm{NaCl}$ (Affecting by cellular membrane integrity by osmotic stress) (McDonnell and Russell, 1999) and Povidone iodine (Affecting by react with functional groups example : $-\mathrm{OH}$ (reaction with the phenolic group of tyrosine),
-NH2, (amino acids and nucleotide bases), -SH (cysteine) and with $\mathrm{C}=\mathrm{C}$ bonds of unsaturated fatty acids. This reactive groups have essential functions in the metabolic processes of yeast and Bacteria (Gottardi, 1985). These metabolic processes are interrupted by the binding of iodine and the microorganisms are thus inactivated) were showed low antifungal effects against $B$. sanguinis in comparison with other agents which appeared high potency as antifungal, this may be result for several reasons. First cause :- B. sanguinis may be resistance to biocides result from overuse or misuse of antiseptics to treat fish fungi or may be exposure to a lower sub-lethal concentration (McDonnell and Russell,1999). Second caused, the antiseptics (Methylene blue, Potassium permanganate, $\mathrm{NaCl}$ and Povidone iodine) at concentration used may be not effect on the $B$. sanguini and This supports the findings of the present study.

One of the main problems experienced by fish breeders in Iraq is the frequent occurrence of fungal infections in carp (in enclosed ponds and floating cages). At the same time, the indiscriminate use of antiseptics and not follow recommended concentrations by the manufacturer have led to the failure of some these substances as a treatment. This is consistent with the current study which showed some antiseptics substances ineffective against $B$. sanguinis .

\section{ACKNOWLEDGMENTS}

We acknowledge the effort of Ms. Zahra Noori Abbas for providing technical assistance in the course of this research.

\section{CONFLICT OF INTEREST}

The authors declare that there are no conflicts of interest.

\section{REFERENCES}

1. Bogdanffy, M.S., Morgan P.H., Starr T.B. and Morgan K.T. Binding of formaldehyde to human and rat nasal mucus and bovine serum albumin. Toxicol. Lett., 1987; 38:145-154.

2. Bras, M., Queenan, B. and Susin, S.A. Programmed cell death via mitochondria: different modes of dying. Biochemistry (Mosc.), 2005; 70: 231-239.

3. Block, S. S., Definitions of terms, p. 18-125. In S. S. Block (ed.), Disinfection, sterilization, and preservation, 4th ed. Lea \& Febiger, Philadelphia, Pa., 1991. 
4. Cruickshank, R., Duguid, J.P. and Marmion, B.P. Tests for sensitivity of antimicrobial agents. Med. Microbiol., 1975; 190-208.

5. Epe, B., Hegler J. and Wild, D. Singlet oxygen as an ultimately reactive species in Salmonella typhimurium DNA damage induced by methylene blue/visible light. Carcinogenesis, 1989; 10: 2019-2024..

6. Gottardi, W. The influence of the chemical behavior of iodine on the germicidal action and disinfectant solution containing iodine. J. Hosp. Infect., 1985; 6(Suppl), 1.

7. Hussein, I. M., Abed, A. R. and Abbas, H. A., In Vitro Study the Effects of Anti-ungal Agents on the Mycelial Growth of Aspergillus Niger. Indian Journal of Public Health Research \& Development, 2018; 9: 338-343.

8. Idowu, T.A., Adedeji, H.A. and Sogbesan, O.A. Fish Disease and Health Management in Aquaculture Production. Int. J. Environ. \& Agri. Sci., 2017; 1: 1 pp2-6.

9. Koehn J.D., Thwaites, L.A., Zampatti, B., Dodd, L., Todd, C., Stuart, I., Ye Q. and Stamation, K. Managing flows and Carp. Arthur Rylah Institute for Environmental Research Technical Report Series No. 255. Arthur Rylah Institute for Environmental Research, Department of Environment, Land, Water and Planning, Heidelberg, Victoria, 2016

10. Kowaltowski, A.J., Turin, J., Indig, G.L. and Vercesi, A.E. Mitochondrial effects of triarylmethane dyes. J. Bioenerg. Biomembr., 1999; 31: 581-590.

11. Kumbhar, A.S., Padhye, S.B., Saraf, A.P., Mahajan, H.B. Chopade, B.A. and West, D.X. Novel broad-spectrum metal-based antifungal agents. Correlations amongst the structural and biological properties of copper 2-acetylpyridine N4- dialkylthiosemicarbazones.
Biology of metals, 1991; 4: 3141-3143.

12. Magaldi, S., Mata-Essayag, S., Hartung de Capriles, C., Perez C., Colella, M.T., Olaizola, C. and Ontiveros, Y. Well diffusion for antifungal susceptibility testing. Int. J. Infect. Dis., 2004; 8, 39-45.

13. McDonnell, G. and Russell, A.D. Antiseptics and disinfectants: activity, action, and resistance. Clin. Microbiol. Rev., 1999; 12: 147-179.

14. Mohit K., Mohammed, F., Satyapal S., Anwar, S. and Ashok, K.B. Antifungal activityof the Eucalyptus australe important medicinal plant. International Journal of Engineering Science Invention, 2013; 2: 3027.

15. Nasiru, A.M., Banwo, O.O., Isah, A.D. and Zarafi, A.B. Identification and pathogenicity of fusarium and phomopsis foliar diseases of Jatropha curcas L. in North-west States of Nigeria. World Research Journal of Agricultural Sciences, 2015; 2: 022-027.

16. Sen, K. and Mandal, R. Fresh-water fish diseases in west Bengal, India. International Journal of Fisheries and Aquatic Studies, 2018; 6:356-362 .

17. Srivastava S., Sinha, R. and Roy, D. Toxicological effects of malachite green. Aquat. Toxicol., 2004; 66, 319-329.

18. Tischer, M., Pradel, G., Ohlsen, K. and Holzgrabe, U., Quaternary ammonium salts and their antimicrobial potential: targets or nonspecific interactions? Chem. Med. Chem., 2012; 7: 22-31. http://dx.doi.org /10.1002/cmdc. 201100404.

19. Zahn, T. and Braunbeck, T. Cytotoxic effects of sublethal concentrations of malachite green in isolated hepatocytes from rainbow trout (Oncorhynchus mykiss). Toxicol. In vitro, 1995; 9: 729-741. 